\title{
Giresun Yöresine Ait Sakarca (Ornithogalum Umbellatum L.) Bitkisinde Toplam Fenolik Madde, Toplam Flavonoid Madde ve İyon Kromatografik Anyon- Katyon İçeriklerinin Tayinleri
}

\author{
Elif APAYDIN ${ }^{1 *}$, Murat YOLCU ${ }^{2}$ \\ ${ }^{1}$ Giresun Üniversitesi Merkezi Araştırma Lab. Uygulama ve Araştırma Merkezi, Giresun, Türkiye \\ ${ }^{2}$ Giresun Üniversitesi, Fen-Edebiyat Fak. Kimya Bölümü, Giresun, Türkiye
}

Geliş Tarihi: 14.10 .2017

*Sorumlu Yazar: eliferenapaydin@gmail.com

Kabul Tarihi: 30.11 .2017

\section{Özet}

$\mathrm{Bu}$ çalışmada Giresun yöresinde bolca yetişen sakarca (Ornithogalum umbellatum L.) bitkisinin taze ve diyet olarak kullanılan halinin toplam fenolik madde, toplam flavonoid madde ve anyon-katyon içeriklerinin tayini amaçlanmıştır. Taze ve ısıl işlem görmüş bitki numuneleri doğrayıcı ile küçültülmüş ve metanol ile soxhlet ekstraksiyonu yapılmıştır. Bitki ekstraktlarında toplam fenolik madde tayini Folin Ciocalteu yöntemiyle ve toplam flavonoid madde tayini ise alüminyum nitrat yöntemi ile yapılmıştır. Ayrıca sakarca bitkisinin bazı anyon-katyon içeriği Dionex ICS-5000 iyon kromatografi sistemi ile eşzamanlı olarak belirlenmiştir.

Anahtar Kelimeler: Ornithogalum umbellatum L., sakarca, fenolik madde, flavonoid madde, iyon kromatografi

\section{Total Phenolic and Total Flavonoid Compounds and Ion Chromatographic Anions and Cations Determinations of Giresun Region's Sakarca Plant (Ornithogalum Umbellatum L.)}

\begin{abstract}
In this work; total phenolic compounds and total flovonoid compounds have been identificated of the fresh and diet of Sakarca (Ornithogalum umbellatum L.) plant which has been abundantly grown in Giresun. Fresh and cooked plant samples were shredded and extracted with soxhalet in methanol. Total phenolic contents of the were determined by Folin Ciocalteu method and total flavonoid contents of the studied samples were determined by aluminum nitrate method. In addition, some anion-cation content of samples were simultaneously determined by the studied samples Dionex ICS-5000 ion chromatography system.
\end{abstract}

Keywords: Ornithogalum umbellatum L., sakarca, phenolic compound, flavonoid compound, ion chromatography 


\section{Giriş}

Antioksidanlar, serbest radikallerin oluşumunu önleyen bileşenler olarak ifade edilir. (Düzgüner, 2005). Antioksidanlar, organizma veya besinlerde düşük derişimlerde bulunduğunda oksidasyonu büyük oranda geciktirir veya engeller (Ghosh ve Myers, 1998). Yine antioksidan; karbonhidrat, protein, lipid ve nükleik asitler gibi yükseltgenebilir bir substrat ile karşılaştığında, substratın oksidasyonunu kayda değer ölçüde geciktiren ya da önleyen maddedir (Yin ve ark., 1995)

Antioksidan maddelere örnek olarak; Alfa tokoferol (E vitamini), beta-karoten (A vitamini), askorbik asit (C vitamini), fenolik maddeler ve flavonoidler verilebilir (Shadidi, 1997). Fenolik maddeler ve flavonoidler insan besinlerinde bulunan ve bitkilerde de çok olan fenolik yapıda bileşiklerdir. Gıdalarda bulunan gallik asit, kuersetin, mirisetin ve kemferol gibi flavonoidler ve fenolik bileşiklerin antimikrobiyal, antiviral ve antioksidan gibi geniş bir biyolojik spektrumu vardır (Huang ve ark., 2005). Flavonoidler $\mathrm{C}_{6}-\mathrm{C}_{3}-\mathrm{C}_{6}$ yapısındaki 15 karbonlu bileşiklerdir. Flavonoidler aromatik halkalara bağlı antioksidan aktivitelerini oluşturan birçok fenolik hidroksil grupları içerirler (Rice-Evans ve ark., 1997).

Sakarca bitkisi (Şekil 1.) Türkiye'de çökülce ve çiğdem gibi isimlerle de bilinen, Orta ve Doğu bölgeleri olmak üzere tüm Karadeniz'de ve genellikle fındık bahçelerinin kenarlarında doğal olarak yetişen, 20-30 cm boyunda çok yıllık, otsu bir bitkidir (Anonim, 2013). Literatürde sakarca bitkisi ile ilgili çeşitli çalışmalar mevcuttur; toplam fenolik ve flavonoid madde tayinleri farklı metotlarla yapılmış olup, antioksidan özellik gösterdiği yapılan çalışmalarda ortaya konulmuştur (Özen, 2010). $\mathrm{Bu}$ biyokimyasal özelliklere ilaveten; sakarca bitkisinin yaygın anyon-katyon içeriği araştırılmak istenmiştir. Yaygın anyon ve katyonların eş zamanlı tayinleri için iyon kromatografi sistemi yaygın olarak kullanılmaktadır (Haddad ve Jackson, 1990).

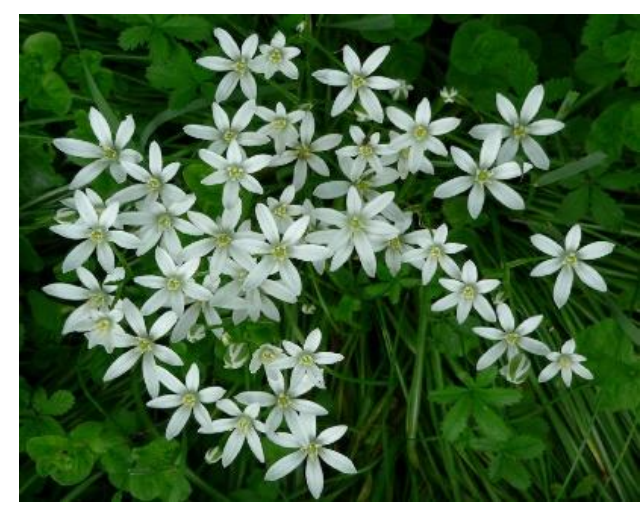

Şekil 1. Sakarca bitkisi (alankentv.blogspot.com). 
Bu çalışmada, Giresun yöresine ait sakarca bitkisinin toplam fenolik madde, toplam flavonoid madde tayinlerinin literatürde yer alan metotlardan farklı metotlarla yapılması ve buna ilaveten bazı anyon-katyon içeriklerinin belirlenmesi amaçlanmıştır.

\section{Materyal ve Metot}

\subsection{Kullanılan Kimyasal Maddeler}

Metanol, gallik asit, kuersetin, Folin-Ciocaltaeu reaktifi, sodyum karbonat, alüminyum nitrat Sigma Aldrich firmasından; metansülfonik asit, sodyum karbonat (0,5 M), altı katyon-II standardı ve yedi anyon standardı Dionex-Thermo Scientific firmasından temin edilmiştir.

\subsection{Kullanılan Alet ve Cihazlar}

Dionex ICS-5000 iyon kromatografi sistemi, soxhlet ekstraksiyon düzeneği, Thermo Scientific UV-Vis Spektrrofotometre, Sartorious ultra saf su sistemi.

\subsection{Bitkisel Materyal ve Ekstraksiyon Aşaması}

Sakarca bitkisi Giresun merkezden toplanmıştır. Taze ve 15 dakika ısıl işlem görmüş halde iki farklı metanol ekstraksiyon yöntemi uygulanmıştır. Soxhlet düzeneğinde metanol ile 8 saat boyunca ektsrat toplanmıştır. İşlem sonrasında analizler gerçekleştirilmiştir.

\subsection{Folin Yöntemiyle Toplam Fenolik Madde Tayini}

Toplam fenol miktarı Folin-Ciocaltaeu yöntemine göre yapılmıştır (Gamez ve ark., 1999). Bu yönteme göre 0,5 mL örnek, 2,5 mL Folin-Ciocaltaeu reaktifi (\%10'luk, h/h, suda) ve 7,5 mL sodyum karbonat çözeltisi (\%20'lik, a/h, suda) deney tüpüne karıştırılarak 2 saat oda sıcaklığında bekletilmiştir. Aynı işlem bir fenolik madde türü olan gallik asitin farklı derişimlerdeki standart çözeltilerine de uygulanmış ve elde edilen verilerden standart grafiği oluşturulmuştur. Sonrasında numune ve standart çözeltilerin absorbansları $750 \mathrm{~nm}$ dalga boyunda UV spektrofotometresinde ölçülmüştür. Toplam fenolik madde içeriği mg gallik asit eşdeğeri/gram ekstrakt olarak ifade edilmiştir. 


\subsection{Toplam Flavonoid Madde Tayini}

Bitki ekstraktının toplam flavonoid madde miktarı, kuersetine eşdeğer olarak modifiye edilmiş alüminyum nitrat yöntemi ile belirlenmiştir (Moreno ve ark., 2000). Toplam flavonoid madde tayini için $10 \mathrm{mg} / \mathrm{mL}$ derişimindeki bitki ekstraktından $0,5 \mathrm{~mL}$ alınarak üzerlerine $0,1 \mathrm{~mL}$ sodyum asetat eklenmiş ve 1 dakika sonra da $0,1 \mathrm{~mL} \% 10^{\prime}$ luk (w/v) $\mathrm{Al}\left(\mathrm{NO}_{3}\right)_{3}$ ilave edilerek çalkalanmıştır ve \%96'lık (v/v) etanol ile hacimleri 5 mL'ye tamamlanmıştır. Oda sıcaklığında 40 dakika bekletilen karışımların absorbans değerleri $450 \mathrm{~nm}$ dalga boyunda ölçülmüş ve toplam flavonoid madde içeriği mg kuarsetin eşdeğeri (QE)/gram ekstrakt olarak ifade edilmiştir.

\section{6. İyon Kromatografi Sistemi ile Bazı Anyon-Katyon Tayini}

Bitki ekstraktlarında Dionex ICS-5000 sistemi ile eş zamanlı anyon-katyon analizleri yapılmıştır. Anyon (florür, klorür, nitrit, bromür, nitrat, fosfat, sülfat) analizleri Dionex Ion Pac AS 9 HC (4x250 mm with guard column) ayrım kolonunda $10 \mathrm{mM}$ sodyum karbonat yürütücü fazı (akış hızı: $1 \mathrm{~mL} /$ dak) ile gerçekleştirildi. Katyon (lityum, sodyum, amonyum, potasyum, magnezyum, kalsiyum) analizleri Dionex Ion Pac CS 12 A (3x150 mm with guard column) ayrım kolonunda 20 mM metasülfonikasit yürütücü fazı (akış hızı: $0,5 \mathrm{~mL} /$ dak) ile gerçekleştirildi. Katyon baskılayıcı kolon olarak Dionex CERS 500 (2 mm) ve anyon baskılayıcı kolon olarak Dionex AERS 500 (4 mm) kullanıldı. Numuneler oto örnekleyici ile $20 \mu \mathrm{L}$ hacimlerde kolona verildi. Sistemde Thermo Scientific iletkenlik dedektörü kullanıldı ve Chromeleon yazılım sistemi ile hesaplamalar yapıldı.

\section{Bulgular ve Tartışma}

\subsection{Toplam Fenolik Madde ve Toplam Flavonoid Madde Tayinleri}

Folin yöntemiyle belirlenen toplam fenolik madde içerikleri gallik asit eşdeğeri olarak ve alüminyum nitrat yöntemi ile belirlenen toplam flavonoid madde içerikleri kuersetin eşdeğeri olarak hesaplanmıştır. Elde edilen sonuçlar Tablo 1.' de verilmiştir.

Tablo 1. Sakarca bitki ekstraktlarının toplam fenolik madde ve toplam flavonoid madde içerikleri.

\begin{tabular}{ccc}
\hline Numune tipi & $\begin{array}{c}\text { Toplam fenolik madde miktarı* } \\
\text { (mg / g kuru bitki) }\end{array}$ & $\begin{array}{c}\text { Toplam flavonoid madde miktarı** } \\
\text { (mg / g kuru bitki) }\end{array}$ \\
\hline Taze Bitki & $5,821 \pm 0,008$ & $3,258 \pm 0,028$ \\
\hline Pişirilen Bitki & $5,056 \pm 0,004$ & $2,546 \pm 0,052$ \\
\hline
\end{tabular}

\footnotetext{
* mg gallik asit eş değeri/ gram kuru bitki olarak $n=3$ için ortalama ve standart sapması ile verilmiştir.

** mg kuersetin eşdeğeri / gram kuru bitki olarak $n=3$ için ortalama ve standart sapması ile verilmiştir.
} 
Elde edilen bulgulardan; Giresun yöresinde yaygın olarak yetişen sakarca bitkisinin uygulanan metotlar ile toplam fenolik madde ve toplam flavonoid maddece zenginliği bir kez daha belirlenmiştir. Giresun'da bolca yetişen ve literatürde yer alan bazı diğer bitkilerden olan merevcenin (Smilax excelsa L.) benzer metotlarla (Chang ve ark., 2002) analiz sonuçları şöyledir; toplam fenolik madde miktarı etanol ekstraktı için $30,1 \pm 1,55 \mathrm{mg} / \mathrm{g}$ ve toplam flavonoid madde miktarı 28,7 $\pm 2,41$ mg/g değerlerindedir (Özsoy ve ark., 2008). Bu bulgular; aynı yörede yetişen iki farklı tür bitkinin, benzer metotla yapılan toplam fenolik madde ve toplam flavonoid madde tayinlerinin farklılığını sergilemektedir. Sakarca bitkisinin merevcen bitkisinden daha az toplam fenolik ve toplam flavonoid madde içerdiği söylenebilir.

\subsection{Eş zamanlı İyon Kromatografik Anyon ve Katyon Analizleri}

Eş zamanlı iyon kromatografik anyon-katyon analizleri için optimum kromatografik şartlar (akış hızı, elüent derişimi, enjeksiyon hacmi vb.) belirlendi. Sonrasında numune analizleri gerçekleştirildi. Elde edilen alıkonma zamanları (Tablo 2.), numune kromatogramları (Şekil 2. ve Şekil 3.), kalibrasyon grafikleri (Şekil 4. ve Şekil 5.) ve numuneler için hesaplanan sonuçlar (Tablo3. ve Tablo 4.) aşağıda sırasıyla verilmiştir.

$\underline{\text { Tablo 2. Anyon ve katyonların alıkonma zamanları }\left(t_{R}\right)}$

\begin{tabular}{cccc}
\hline Anyon & $\mathbf{t}_{\mathbf{R}}(\mathbf{d a k})$ & Katyon & $\mathbf{t}_{\mathbf{R}}(\mathbf{d a k})$ \\
\hline Florür & 4,30 & Lityum & 2,75 \\
\hline Klorür & 6,76 & Sodyum & 3,27 \\
\hline Nitrit & 8,33 & Amonyum & 3,74 \\
\hline Bromür & 10,39 & Potasyum & 4,60 \\
\hline Nitrat & 12,01 & Magnezyum & 7,35 \\
\hline Fosfat & 15,42 & Kalsiyum & 9,10 \\
\hline Sülfat & 17,46 & & \\
\hline
\end{tabular}




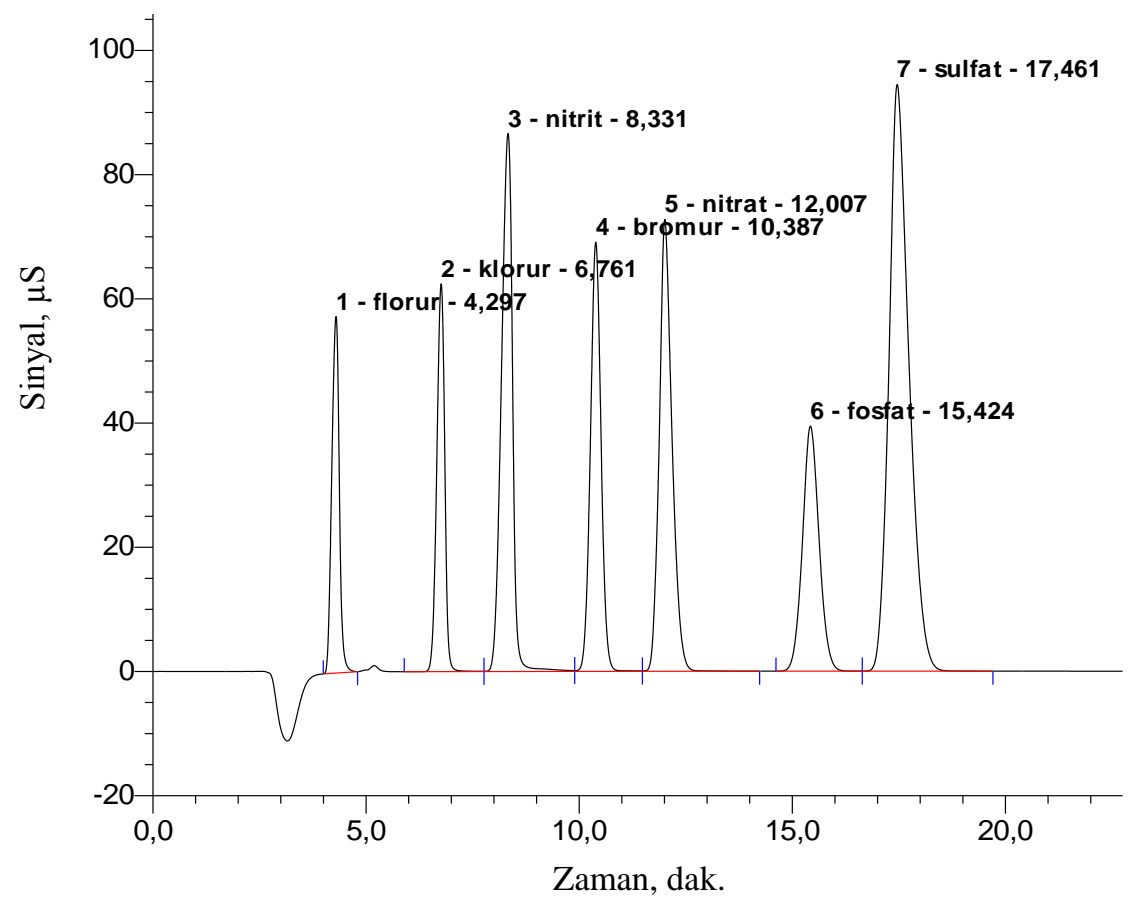

Şekil 2. 3 ppm anyon standardı için elde edilen IC kromatogramı.

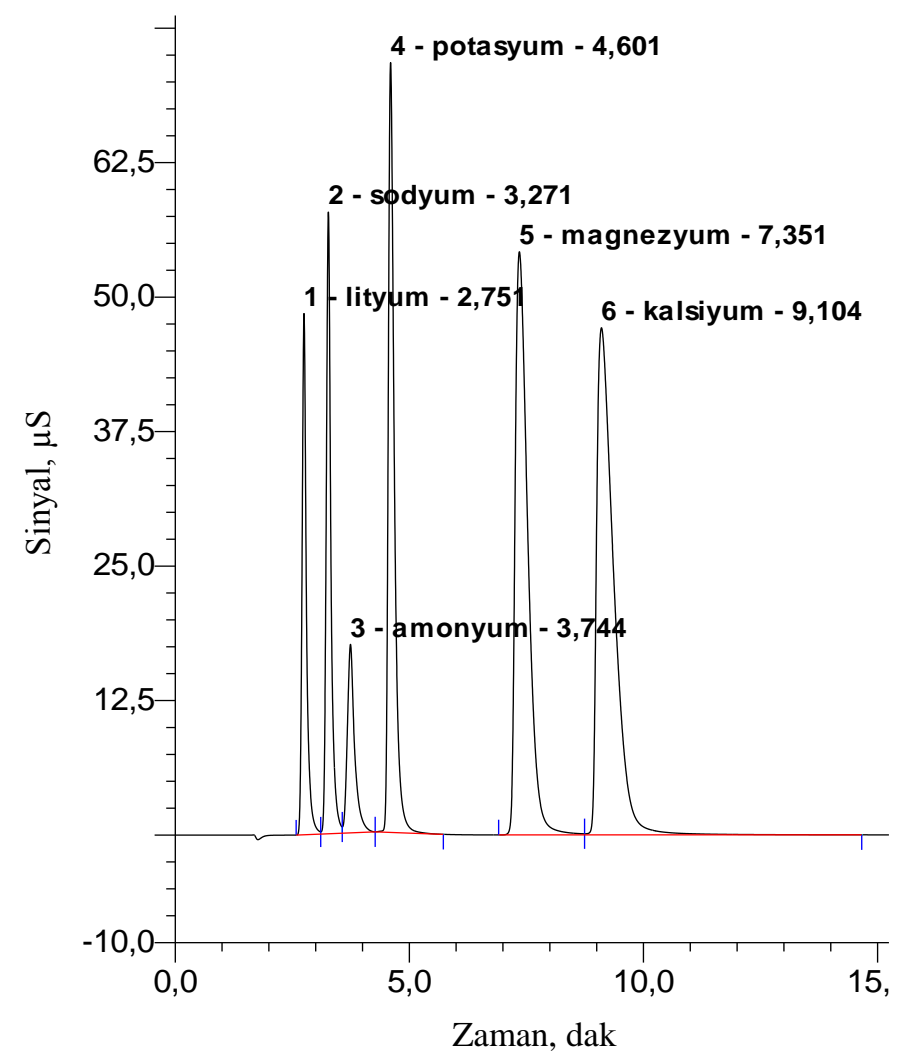

Şekil 3. 3 ppm katyon standardı için elde edilen IC kromatogramı. 

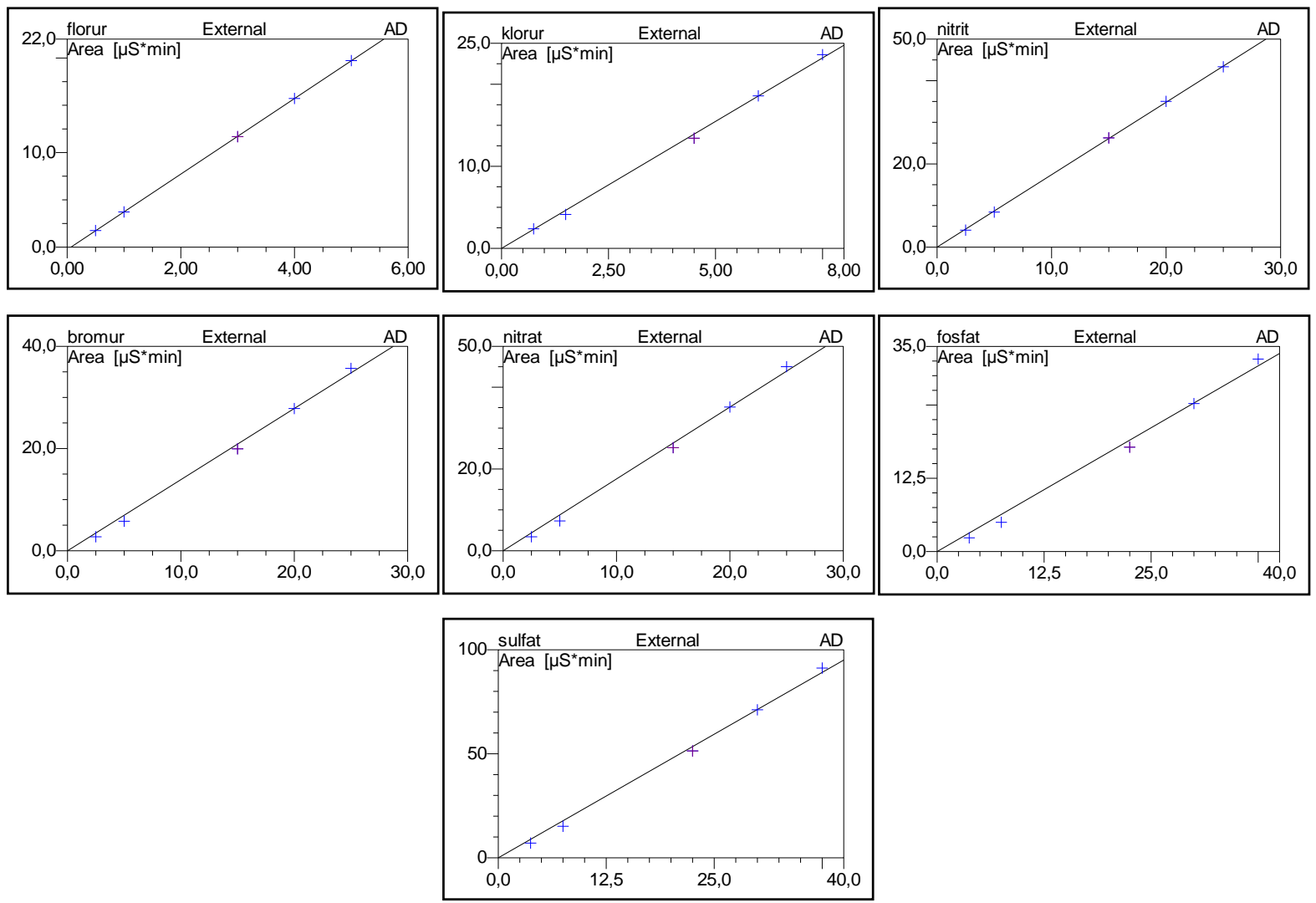

Şekil 4. IC sisteminde anyonlar için elde edilen kalibrasyon grafikleri
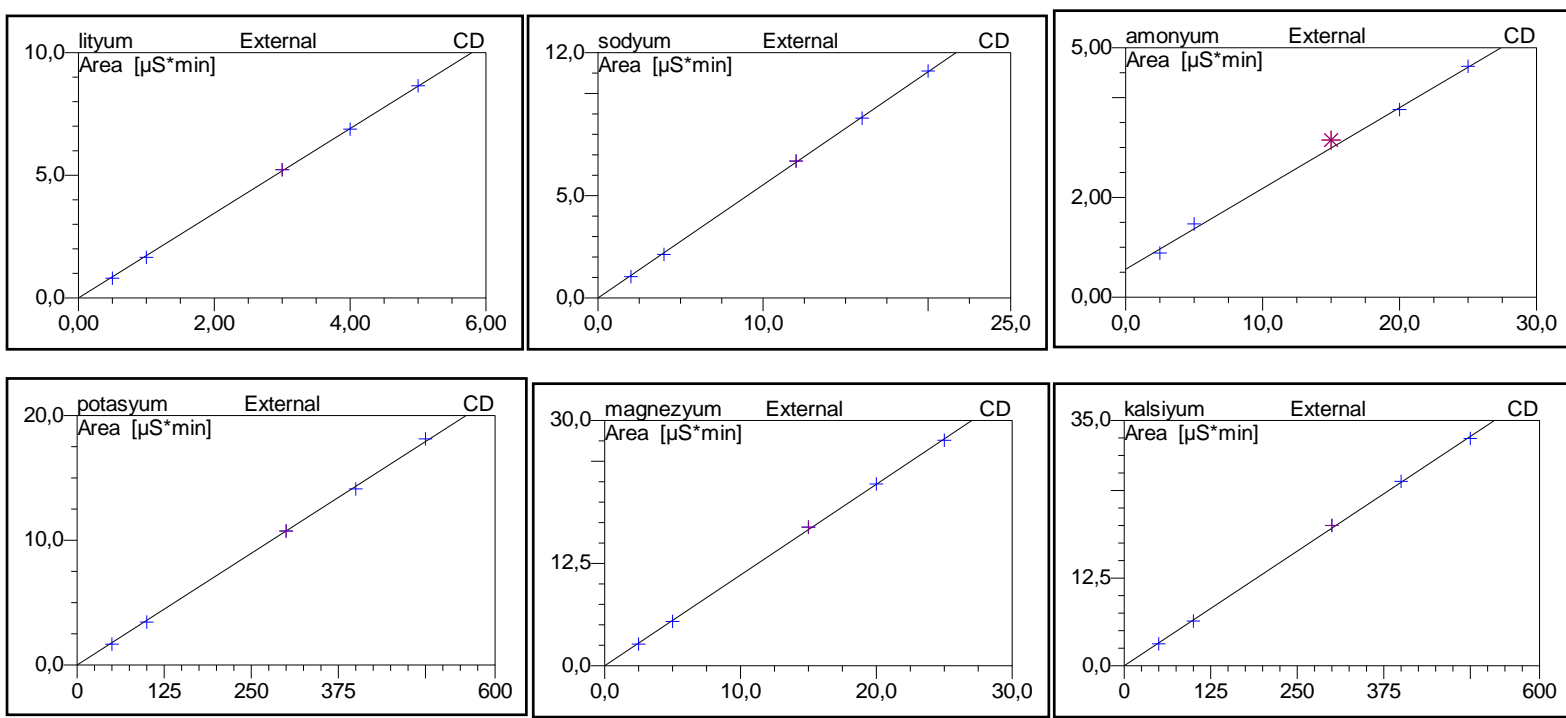

Şekil 5. IC sisteminde katyonlar için elde edilen kalibrasyon grafikleri 
Tablo 3. Bitki ekstraktları için bulunan anyon miktarları* $(\mathrm{ppm})$

\begin{tabular}{ccc}
\hline Anyon & Taze bitki & Isll işlem görmüş bitki \\
\hline Florür & $4,18 \pm 0,12$ & $0,72 \pm 0,14$ \\
\hline Klorür & $43,30 \pm 0,13$ & $32,30 \pm 0,17$ \\
\hline Nitrit & - & - \\
\hline Bromür & - & - \\
\hline Nitrat & $43,21 \pm 1,31$ & $57,73 \pm 0,49$ \\
\hline Fosfat & $45,30 \pm 0,23$ & $113,42 \pm 0,32$ \\
\hline Sülfat & $<$ LOD $^{* *}$ & $<$ LOD $^{* *}$ \\
\hline *n=3 için ortalama ve standart sapması ile verilmiştir. \\
** Tayin Limiti
\end{tabular}

Tablo 4. Bitki ekstraktları için bulunan katyon miktarları* (ppm)

\begin{tabular}{ccc}
\hline Katyon & Taze bitki & Isll işlem görmüş bitki \\
\hline Lityum & - & - \\
\hline Sodyum & $414,57 \pm 0,19$ & $401,59 \pm 0,35$ \\
\hline Amonyum & $1003,98 \pm 9,54$ & $1041,12 \pm 10,14$ \\
\hline Potasyum & $1509,55 \pm 10,54$ & $3250,83 \pm 15,59$ \\
\hline Magnezyum & $19,12 \pm 1,53$ & $19,41 \pm 0,08$ \\
\hline Kalsiyum & $22,55 \pm 0,15$ & $23,22 \pm 0,16$ \\
\hline
\end{tabular}

*n=3 için ortalama ve standart sapması ile verilmiştir.

\section{Sonuçlar ve Öneriler}

Bu çalışma; sakarca bitkisinin fenolik ve flavonoid özelliklerinin yanı sıra bazı yaygın anyon ve katyon içeriğinin belirlenmesi amacıyla yapılmıştır. Elde edilen toplam fenolik ve toplam flavonoid madde miktarları sonuçlarına göre sakarca bitkisinin antioksidan özellikte bir bitki olduğu bir kez daha desteklenmiştir. Isıl işlem görmüş bitki ekstraktının toplam fenolik ve toplam flavonoid madde miktarında çok az da olsa azalma görülmüştür. Isıl işlemin bitkinin antioksidan özelliğini azaltıcı etkisi olduğu sonucuna varılabilir. Elde edilen iyon kromatografik sonuçlardan bitkinin içerdiği katyonik türlerin anyonik türlere göre daha fazla olduğu belirlenmiştir. Bitkinin değişen miktarlarda florür, klorür, nitrat ve fosfat anyonları ile sodyum, amonyum, potasyum, magnezyum ve kalsiyum katyonlarını içerdiği belirlenmiştir. Ayrıca bitkiye uygulanan 1sıl işlemin, bitkinin iyon içeriklerine arttırıcı yönde etki ettiği belirlenmiştir. 


\section{Kaynaklar}

Anonim (2013). http://otekiyuz.com/ornithogalum-umbellatum-namidiger-sakarca/ (Erişim tarihi: 10.08. 2017)

Düzgüner, V., (2005). Deneysel olarak diyabet oluşturulan tavşanlarda çinkonun lipid peroksidasyonu ve antioksidan sistem üzerine etkisi. Yüksek Lisans Tezi, Mustafa Kemal Üniversitesi, Sağlık Bilimleri Enstitüsü, Hatay.

Chang, L.W., Yen, W.J., Huang, S.C. and Duh, P.D. (2002). Antioxidant activity of sesame coat. Food Chemistry, 78, 347-354

Gamez-Meza, N., Noriega-Rodriguez, J.A., Medina-Juarez, L.A., Ortega-Garcia, J., Cazarez-Casanova, R., and Angulo-Guerrero, O. (1999). Antioxidant activity in soybean oil of extracts from thompson grape bagasse. The Journal of the American Oil Chemists' Society, 76, 1445.

Ghosh, J., and Myers, C.E. (1998). Inhibition of arachidonate 5-lipoxygenase triggers massive apoptosis in human prostate cancer cells. Proceedings of the National Academy of Sciences, 95(22), 13182-7.

Haddad P.R., and Jackson P.E. (1990). Ion chromatography: Principles and Applications. Elsevier Science Publishers B.V., 775.

Huang, D., Ou, B. and Prior, R. L. (2005). The Chemistry Behind Antioxidant Capacity Assays, Journal of Agriculture and Food Chemistry, 53, 1841-1856.

Moreno, M.I.N., Isla M.I., Sampietro, A.R., and Vattuone, M.A. (2000). Comparison of the free radicalscavenging activity of propolis from several regions of Argentina. Journal of Ethnopharmacol, 71, 109114.

Özen, T. (2010). Antioxidant activity of wild edible plants in the Black Sea Region of Turkey. International Journal of Fats and Oils, 61(1), 86-94.

Özsoy, N., Can, A., Yanardağ, R. and Akev, N. (2008). Antioxidant activity of Smilax excelsa L. leaf extracts. Food Chemistry, 110, 571-583.

Rice-Evans, C.A., Miller, N.J., and Paganga, G.(1997). Antioxidant properties of phenolic compounds. Trends in Plant Science, 2, 152-159.

Shahidi F. (1997). Natural Antioxidant: Chemistry, Health Effects and Applications, AOCS Press, Champaigh, 25:124-4.

Yin, G.Y., Yin, Y.F., and He, X.F. (1995). Effect of zhuchun pill on immunity and endocrine function of elderly with kidney-yang deficiency. Zhongguo Zhong Xi Yi Jie He Za Zhi, 15(10), 601-3. 